\title{
The public, the press, and tobacco research
}

\author{
Thomas P Houston, Paul M Fischer, John W Richards Jr
} Preventive Medicine and Public Health, American Medical Association, Chicago, Illinois 60610, USA

T P Houston

\section{Department of} Family Medicine, Medical College of Georgia, Augusta,

Georgia 30912, USA

$P$ M Fischer

J W Richards Jr

Correspondence to: $\mathrm{Dr}$ Houston.
Department of

\begin{abstract}
Articles that are written in a manner that is easily understandable by the lay press and that are effectively presented to the media by the medical journals in which they are published can receive a "multiplier" effect when the popular press reports the findings in news stories. This was the case with three articles concerning the $R J$ Reynolds advertising campaign using the "Old Joe" cartoon camel and its appeal to children that were published on 11 December 1991 in the Journal of the American Medical Association (JAMA). The editors of $J A M A$ and the authors of one of the $J A M A$ papers prepared carefully for subsequent press attention. The response by the lay press was overwhelmingly positive, indicating the potential for generating substantial media coverage of scientific articles.
\end{abstract}

\section{We don't advertise to children.}

Who are you kidding?

The newspapers and magazines and billboards are filled with cigarette ads. Kids can't help but see them.

How can you expect us to believe you're not trying to reach and influence our children?

We're not surprised if many people feel this way-especially when years of negative publicity have made them totally cynical about our industry.

Nevertheless, we'd like to set the recond straight.

First of all, we don't want young people to smoke. And we're running ads aimed specifically at young people advising them that we think smoking is strictly for adults.

Second, research shows that among all the factors that can influence a young person to start smoking, advertising is insignificant. Kids just don't pay attention to cigarette ads, and that's exactly as it should be.

Finally - and this is sometimes hard for people outside the marketing field to understand-all of our cigarette ads are what we call "brand advertising." Its purpose is to get smokers of competitive products to switch to one of our brands, and to build the loyalty of those who already smoke one of our brands.

At the present there are some 200 different cigarette brands for sale in the U.S. Many of them have only a very small fraction of the total cigarette market. Getting smokers to switch is virtually the only way a cigarette brand can meaningfully increase its business.

That's why we don't advertise to young people.

Of course, if you'd like to share this ad with your children, that would be just fine with us.

\section{R.J. Reynolds Tóbacco Company}

FIGURE 1 Advertisement by the $R \mathcal{F}$ Reynolds Tobacco Company that appeared in Time magazine on 9 April 1984
Legislative policy is largely driven by public opinion, which is in part shaped by the media. Recognising this, the tobacco industry has chosen not to argue its case in the scientific literature, but rather directly in the media. For years the industry has been successful in convincing many Americans that tobacco use does not cause disease, but rather that the relation between smoking and many illnesses is merely a "statistical association." This use of the media is exemplified by the industry's full page advertisements claiming that the results of the multiple risk factor intervention trial (MRFIT) proved that smoking did not lead to heart disease. ${ }^{1}$ The success of the tobacco industry in distorting the cigarette and illness "debate" has been further enhanced by an important consequence flowing from the revenue it provides to magazines for cigarette advertising. As Warner et al have recently shown, magazines that print cigarette advertisements are less likely to print articles about the hazards of smoking. ${ }^{2}$

Likewise, the tobacco industry has gone to great lengths to convince the public that cigarette advertising does not promote smoking and that its advertising is not directed at adolescents. This position, which is not supportable by scientific evidence, has been actively promoted to the public in full page advertisements (figure 1).

For public opinion and therefore public policy to change the results of medical, behavioural, and social research about smoking must reach the public, not just the scientific community. Phillips et al have recently shown that press coverage of scientific literature amplifies the transmission of research both within and outside the scientific community. ${ }^{3}$

Aware of the multiplier effect of media coverage of health related research, the editors and publisher of the fournal of the American Medical Association ( $\mathcal{F A M A}$ ) have been able to focus attention on important public health issues in at least three ways:

- Regular use of "theme issues" such as a series of tobacco related issues in recent years

- Use of media symposia at the time of the release of these issues

- Use of video news releases to increase television coverage of articles in the journal. ${ }^{4}$

A notable confluence of theme issue and media promotion took place in New York City with a press briefing entitled "Action against 


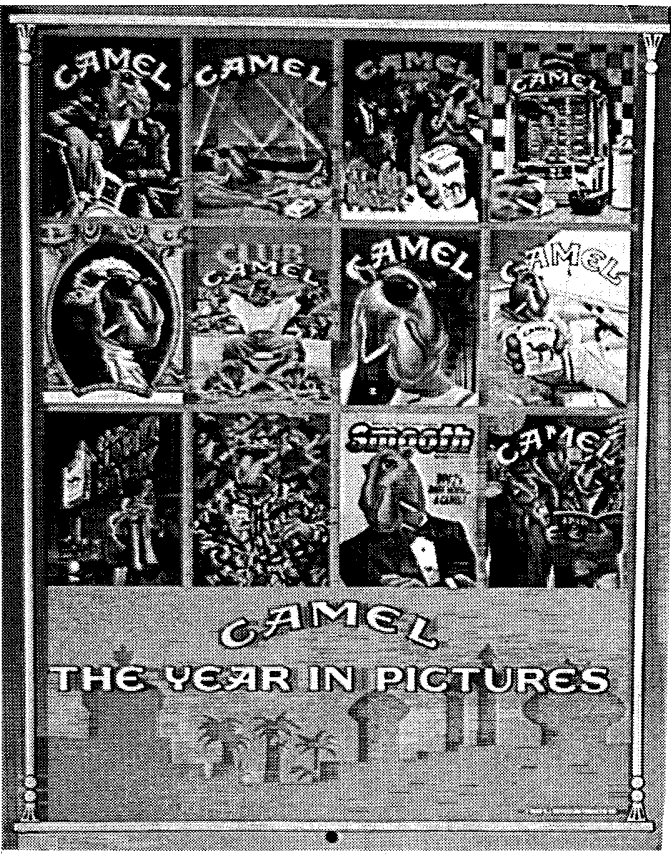

FIGURE 2

smoking: politics, marketing, and treatment" regarding the 11 December 1991 issue of $\mathscr{f} A M A$ on tobacco. The event was timed to coincide with the lifting of $\mathscr{f} A M A$ 's usual news embargo. Information outlining topics to be covered was released by the American Medical Association's scientific information staff to press contacts in advance of the press conference. Selected authors of papers in the issue were invited to represent the subjects addressed. Questions that might be raised by the press about smoking cessation, tobacco advertising and marketing, and methods to decrease youth access to tobacco were researched and attempts were made to anticipate press reaction to these topics.

Two of us with a paper in that theme issue (PMF, JWR) held a separate press conference that coincided with the $\mathcal{F} A M A$ media event.

$=$
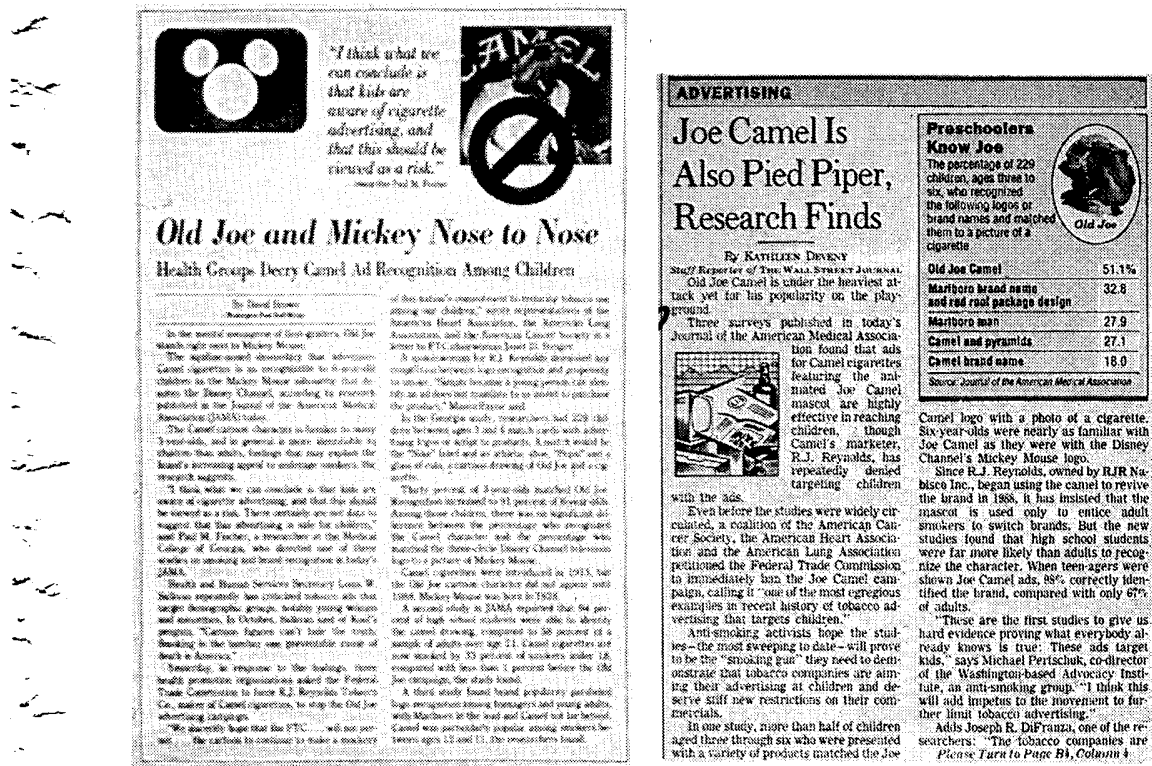

FIGURE 3 Coverage of the JAMA articles in the Washington Post (left) and the Wall Street Journal (right)
This study was specifically designed from its inception with attention to how the research might be covered in the popular press. ${ }^{5}$ In earlier work we had shown that adolescents were very knowledgeable about cigarette advertising themes and that this knowledge was directly associated with smoking rates. ${ }^{6}$ In the study published in $\mathcal{F} A M A$ we sought to:

- Investigate whether tobacco advertising is effective in reaching children much younger than had been previously shown who would be years away from starting smoking. Most previous research had looked at adolescents, the group during which cigarette experimentation first begins. The researchers believed, however, that it would be possible to show tobacco advertising effects in much younger children, who are perceived by the public to be both innocent and vulnerable

- Use research methods that are intuitively understandable by the public. Research that cannot be understood is less likely to be covered by the press and may not be "translated" very well into lay parlance.

- Compare cigarette advertising images with advertising that is known to be specifically targeted at young children. This would provide a useful reference for the public in understanding the effectiveness of the tobacco industry in reaching children audiences.

The study used a game played by 3- to 6year-old children. The children were asked to match a series of product logos to one of 12 products pictured on a gameboard. The study showed that even very young children had extremely high recognition of product logos. This was true for children's products, cigarettes, and some adult products - that is, cars. The analysis that best captured the attention of the press was a comparison of the logo recognition of Mickey Mouse's silhouette as it appears on the Disney Channel and the Old Joe Camel cartoon character (figure 2). By the age of 6 both were recognised by nearly $90 \%$ of the children.

The lay press was extremely helpful in multiplying the exposure of the $\mathcal{F} A M A$ research studies. Extensive articles were carried in most major newspapers (figure 3), weekly news magazines, radio, and each of the national television networks. It was also carried in the international press by outlets in Australia and Argentina, among others. One especially effective piece by Beth Nissen and Carol Williams of ABC World News Tonight highlighted a cute 3 -year-old girl in a day care centre playing the logo recognition game and talking about the Old Joe cigarette cartoon character.

Several newspaper cartoonists used the research finding to ridicule the tobacco industry's position that advertising did not influence decisions by children to smoke (figures 4-10).

Furthermore, because of the horrific thought 


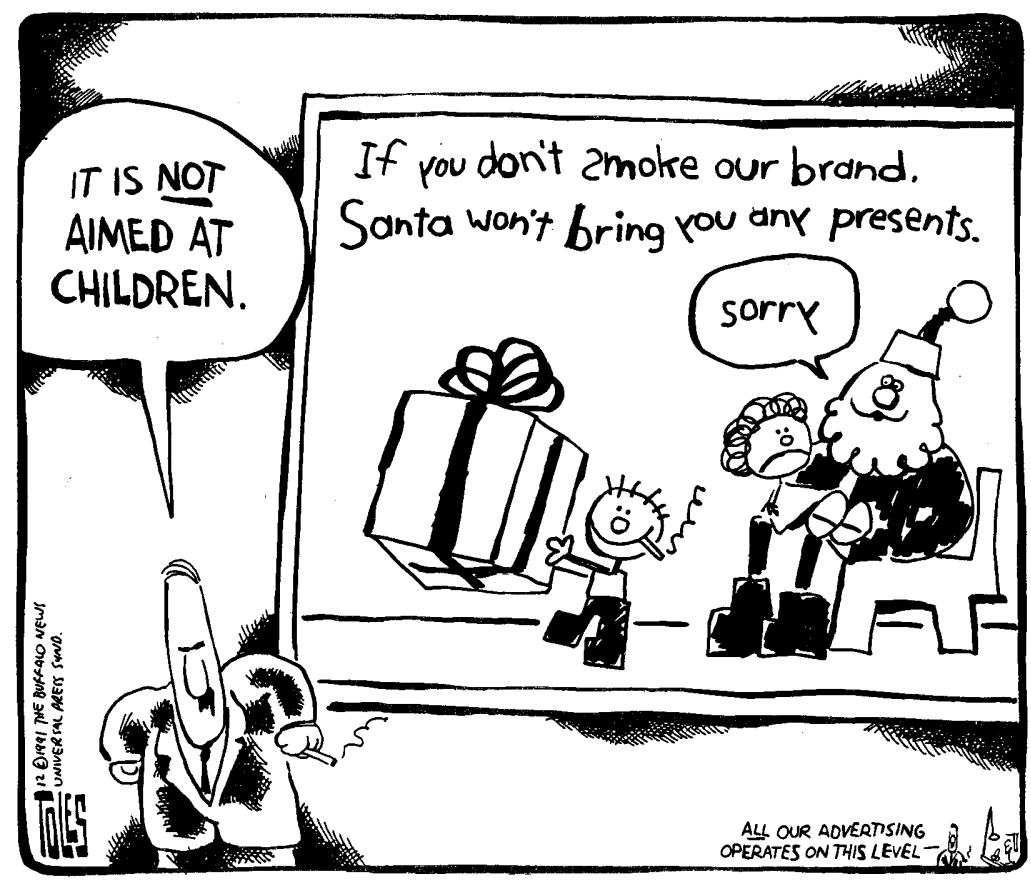

FIGURE 4 By Tom Toles of the Buffalo News. Reprinted with permission

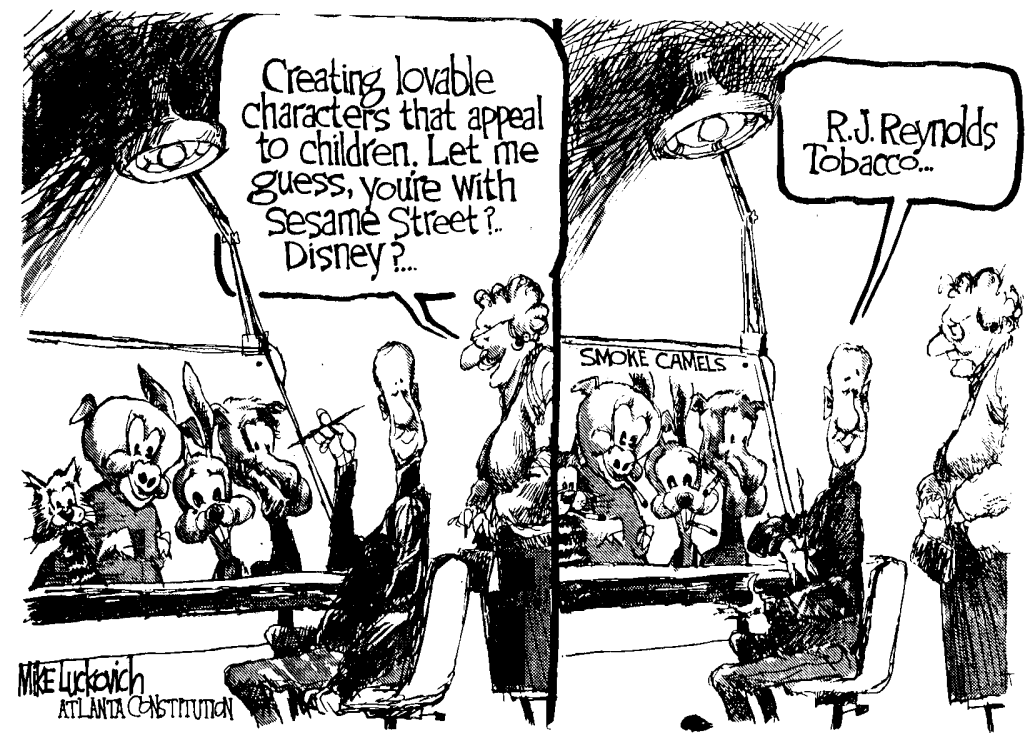

FIGURE 5 Reprinted with permission of Mike Luckovitch and Creators Syndicate

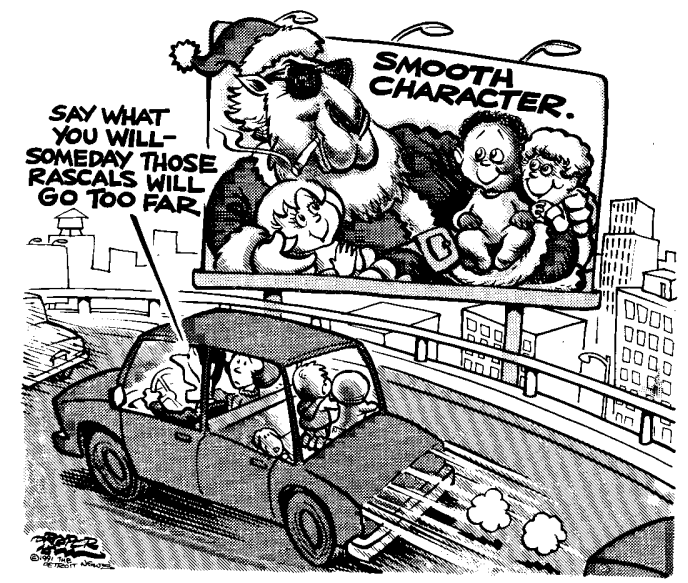

FIGURE 6 By Draper Hill of the Detroit News. Reprinted with permission of the Detroit News, a Gannett newspaper, copyright 1991

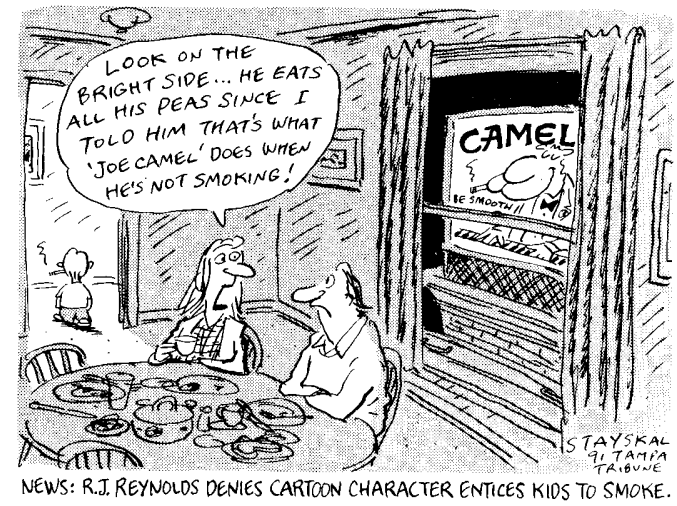

FIGURE 7 By Wayne Stayskal of the Tampa

Tribune. Reprinted with permission

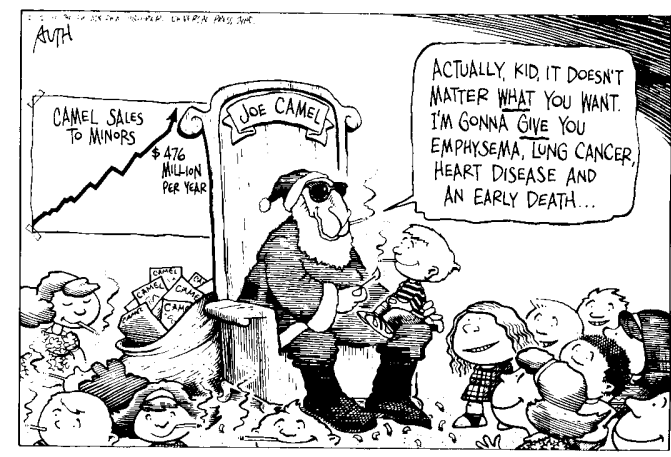

FIGURE 8 By Auth, copyright 1991 Philadelphia

Inquirer. Reprinted with permission of Universal Press Syndicate. All rights reserved

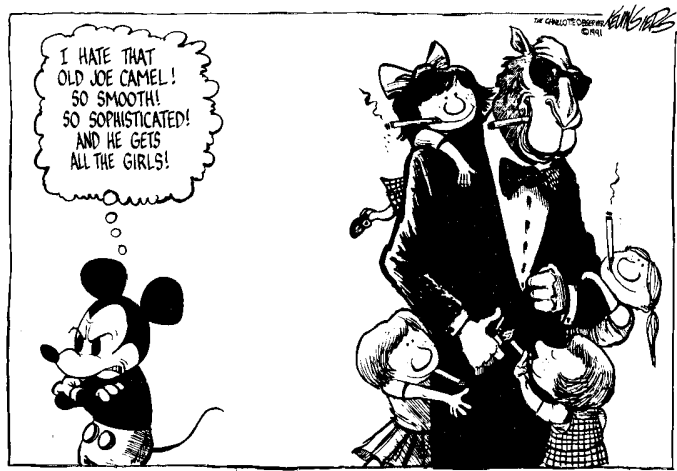

FIGURE 9 By Kevin Spiers of the Charlotte Observer. Reproduced with permission

that cigarette advertising is reaching and possibly influencing 3- to 6-year-old children, many members of the scientific community, the public, and the regulatory and legislative agencies, as well as the advertising and tobacco industries, are now taking a fresh look at tobacco advertising and promotion. A subsequent editorial in Advertising Age, a magazine which has traditionally argued that a tobacco advertising ban would be a violation of the First Amendment, claimed that "[by using] Old Joe... RJR is wrong and is courting disaster with these ads. The company has crossed the divide between its legal right to advertise and its unique social responsibility to the general public...."?

The success of the media's negative view

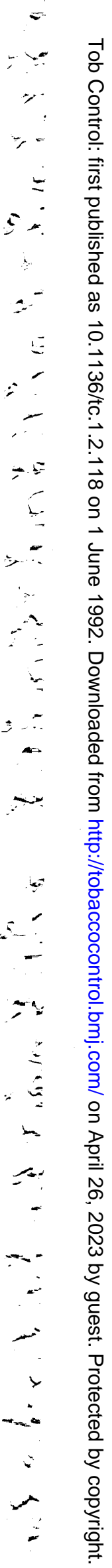

$-2$ 


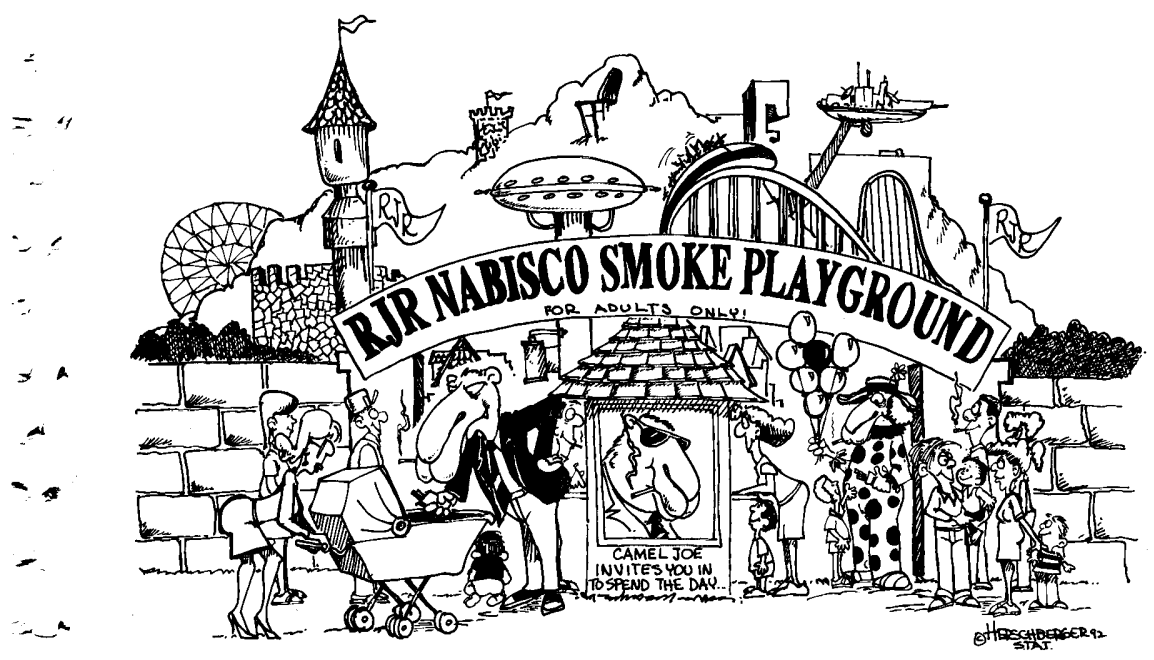

OF COURSE WE DONT EXPECT CHILREN TO BE ATTRACTED TO OR AMUSEMENT PARK...

FIGURE 10 By Vern Herschberger. Reprinted with permission of Stop Teenage Addiction to Tobacco (STAT) behaviour. This strategy has received little attention or sympathy from the press.

By appropriately publicising well crafted articles in the popular media, $\mathscr{f} A M A$ and the authors contributing to its latest tobacco control theme issue have amplified public awareness of important topics. Such collaboration with the lay press can be very useful to tobacco control efforts. ${ }^{89}$

1 Gullen W, Fischer PM, Edelsberg JS, Richards JW, Steinfeld JL. Bad ads: MRFIT misinterpreted. $7 A M A$ $1985 ; 254: 504-5$.

2 Warner KE, Goldenhar IM, McLaughlin CG Cigarette advertising and magazine coverage of the hazards of smoking. N Engl f Med 1992; 326: 305-9.

3 Phillips DP, Kanter EJ, Bendnarczyk B, Tastad PL. Importance of the lay press in the transmission of medical knowledge to the scientific community. $N$ Engl $f$ Med knowledge to the

4 Dan BB. One-minute medicine. $7 A M A$ 1987; 257: 2798.

5 Fischer PM, Schwartz MP, Richards JW, Goldstein AO, Rojas TH. Brand logo recognition by children aged 3 to 6 years: Mickey Mouse and Old Joe the Camel. f $A M A$ 1991 ; 266 : 3145-8.

6 Goldstein AO, Fischer PM, Richards JW, Creten D. Relationship between high school student smoking and recognition of cigarette advertisements. Fournal of Pediatrics $1987 ; 110$ : 488-91.

toward the R J Reynolds "Old Joe" character is also evidenced by the company's attempt to rebut the $\mathcal{F} A M A$ articles with a major campaign defending the tobacco industry's party line about advertising and youth smoking
8 US Department of Health and Human Services. Making health communication programs work: a planner's guide. health commicand prons Bether Communications 89-1493.)

9 Smoke signals: the smoking control media handbook. Atlanta Georgia: American Cancer Society, 1987.
7 Old Joe must go. Advertising Age 1992 Jan; 13: 16. 


\section{Translations of abstract}

\section{Les rapports entre la recherche sur la prevention du tabagisme, et la presse grand public}

Thomas P Houston et al

\section{Résumé}

Lorsqu'ils sont présentés de manière efficace aux media par les journaux médicaux dans lesquels ils sont publiés, les articles scientifiques rédigés dans un style facilement compréhensible par la presse grand public bénéficient d'un effet "multiplicateur": la presse grand public reprend en effet les résultats de ces recherches dans le cadre d'enquêtes et d'articles sur ces sujets.

Cela a été les cas de trois articles concernant la campagne de publicité de Reynolds utilisant le personnage dessiné du chameau "Old Joe": ces articles qui insistaient sur l'attirance des enfants pour pour ces annonces dessinées ont été publiés dans le numéro du JAMA du 11 décembre 1991. Les éditeurs du JAMA et les auteurs de l'un des articles s'étaient particulièrement préparés pour obtenir une bonne couverture de la presse grand public. Celle-ci a répondu d'une manière tout à fait positive, démontrant ainsi la possibilité d'obtenir une couverture médiatique tres substantielle pour des articles scientifiques relatifs à la lutte contre le tabagisme.

\section{El publico, la prensa e investigaciones sobre el tabaco}

Thomas P Houston et al

\section{Resumen}

Los articulos escritos de manera que resulten fácilmente comprensibles para la prensa no especializada y que son presentados con eficacia a los medios de difusión por las revistas médicas que los publican pueden recibir un efecto "multiplicador" cuando la prensa popular comunica sus resultados en forma de reportajes. Esto fue lo que ocurrió con tres artículos referentes a la campaña de publicidad de $\mathrm{R} J$ Reynolds basada en el dibujo cómico del camello "Old Joe" y su atractivo para los niños, los que se publicaron el 11 de diciembre de 1991 en el fournal of the American Medical Association $(\mathcal{F} A M A)$. Los editores de $\mathcal{F} A M A$ y los autores de uno de los articulos se prepararon cuidadosamente para la atención posterior de la prensa. La respuesta de la prensa no especializada fue abrumadoramente positiva, lo que revela las posibilidades de generar una cobertura importante de los artículos científicos por los medios de difusión.

\section{公众, 新闻媒介和烟草研究 托马斯 . 豪斯顿等}

当医学杂志中的研究结果用公众容易理解的语言和形式在新闻媒介中刊载之后, 它就会 产生成倍的收效。

1991 年 12 月 11 日，美国医学杂志发表的三篇关于雷诺烟草公司利用卡通人物 “骆驼老乔” 作烟草广告及其对青少年的诱惑力的文章就是一个例证。美国医学杂志的编辑和文章作者对 新闻界的注意力早有准备。大众媒介的反应令人鼓舞。它显示了用大众媒介报道科学研究结 果的巨大潜力。

(中国健康教育研究所烟草控制与疾病预防研究室 郑保义译) 